\title{
LIMA TEKNOLOGI \\ UNTUK PERUBAHAN PENDIDIKAN
}

"Five Technologies for Educational Change"

( David F. Salisbury)

Educational Technology Publication

Englewood Cliffs, New Jersey 07632

Book report

\section{Ucup Supriatna}

Sekolah Tinggi Agama Islam (STAI) Al-Haudl Ketapang, Kalimantan Barat, Indonesia

\section{BAB I}

\section{PENGANTAR LIMA TEKNOLOGI}

Pendidikan dewasa ini menemukan dirinya dalam ambang revolusi - revolusi metode pada sekolah-sekolah negeri. Bahkan sejak dipublikasikan A Nation at Risk (dilaporkan tahun 1983 oleh komisi khusus gedung putih) para pendidik dan orang-orang yang tertarik dengan dunia pendidikan telah mengusulkan sejumlah rekomendasi untuk pembaharuan. Tahun 1992, President Bush memprakarsai badan pengembangan sekolah baru amerika, yang mendanai kompetisi untuk mendesain tim untuk menemukan "generasi baru sekolah - sekolah amerika" - dan mendobrak sekolah-sekolah dengan kebiasaan tradisional. Pemerintahan Clinton memakai istilah Tujuan 2000, dan menekankan standar pendidikan nasional dan pembaharuan yang lainnya. Whittle komunikasi "Edison Project" mengeluarkan ketetapan rentetan sekolah yang menggabungkan kurikulum yang bersifat inovatif dan teknologi. Sekolah negeri dan swasta seluruhnya memulai usaha restrukturisasi sistem pendidikan. Ahli-ahli politik dan kelompok masyarakat yang memberi dukungan memberikan hadiah, pemilihan sekolah, dan program sertifikasi sekolah yang nampaknya memberikan pengaruh yang kuat terhadap sekolah-sekolah negeri dan kebutuhan sekolah negeri untuk berkompetisi dalam kualitas dan produktifitas. 
Dalam banyak hal, apa yang terjadi dalam pendidikan dewasa ini, sama dengan apa yang telah terjadi dalam perusahaan Amerika seperti perusahaan-perusahaan pribadi dan industri yang sudah menghadapi peningkatan kompetisi dalam pasar global. Bahkan perusahaan terbaik Amerika telah dihadapkan pada :

$>$ memikirkan kembali cara kerja organisasi mereka dan lingkungan dimana mereka beroperasi

$>$ belajar tentang "berpikir sistem" dan menghilangkan pandangan bahwa bagian-bagian beroperasi terpisah, kekuatan yang tidak berhubungan

$>$ mendesain seluruh struktur organisasi baru

$>$ merekayasa ulang seluruh proses

$>$ mengadopsi sistem kualitas dan "Manejemen Mutu Terpadu" agar memenuhi penambahan permintaan dari pelanggan

$>$ mengatur dan dan menyerap sejumlah besar perubahan dalam waktu singkat

$>$ menggunakan alat-alat elektronik modern untuk menambah produktifitas dan memenuhi permintaan pelanggan

Kita baru saja mulai terbangun dari kenyataan bahwa sekolah-sekolah kita akan membutuhkan proses pengalaman yang sama dan menciptakan kembali proses itu, karena mereka secara terus menerus memenuhi keinginan Amerika dalam kualitas, berdayacipta dan memberikan hasil. Sekolah-sekolah seharusnya melihat apa yang perusahaan lakukan dan bagaimana mereka menyelesaikannya. Penyelidikan ini akan memberikan petunjuk besar tentang bagaimana sekolah akan melakukan itu berapa lama hal itu dapat dilakukan.

Hanya membuat perubahan kecil untuk perubahan-perubahan berarti tidak cukup. Kesiapan sekolah-sekolah dan daerah untuk secara teguh melakukan restrukturisasi, reorganisasi, dan program manajemen lingkungan, laboratorium komputer atau kurikulum tematik dengan keyakinan yang merupakan faktor untuk menghasilkan perubahan. Reformasi kecil ini akan mendorong bagian yang lebih besar dari seluruh komponen. Apa yang dibutuhkan untuk transformasi sistem pendidikan dewasa ini kedalam sistem yang secara total berubah seperti perusahaan. Sungguh transformasi akan membutuhkan berpikir kreatif dan produktif, perencanaan dan kerja. Saya menulis buku ini karena saya yakin bahwa perubahan besar penting untuk mendesain ulang yang bermakna pada pendidikan dengan menggunakan lima teknologi baru. 
Dalam lima teknologi terdapat kekuatan untuk membuat sistem pendidikan kita efektif dan membuat sistem yang terbaik sesuai kebutuhan pada dunia modern.

\section{LIMA TEKNOLOGI}

Kelima teknologi ini digunakan secara luas dalam perusahaan dan industri tapi sangat sedikit dalam sekolah-sekolah. Masing-masing dari lima teknologi ini dikembangkan terpisah pada beberapa dekade belakangan. Lima teknologi ini memungkinkan pemimpin industri di seluruh dunia secara efektif membentuk organisasi ke dalam perusahaan yang berorientasi pelanggan. Yang dapat bersaing secara efektif dalam lingkungan global. Kelima teknologi secara bersama-sama menyediakan alat-alat untuk restrukturisasi yang efektif dalam kegiatan pendidikan kita.

Teknologi yang pertama : Berpikir sistem

Berpikir sistem memungkinkan kita menjauhi kebingungan terus menerus oleh ketidakpastian pendidikan. Kebingungan membuat kita melihat perubahan atau perbaikan yang pengaruhnya nampaknya tidak berguna atau bahkan kontraproduktif. Tanpa berpikir sistem, kita sering membuat sesuatu bertambah buruk apa yang kita harapkan menjadi lebih baik. Untuk membuat perbaikan yang nyata, kita harus melihat pendidikan melalui pandangan dengan benar "sistem lensa".

Teknologi yang kedua : Desain Sistem

Desain sistem adalah teknologi yang memungkinkan kita melakukan perubahan atau perbaikan dengan proses sadar. Kebanyakan perubahan dalam pendidikan telah terjadi dalam jumlah yang kecil sekali dan mempunyai pengaruh dalam porsi yang kecil dalam keseluruhan populasi siswa dan lingkungan pendidikan. Kebanyakan perubahan ini bersifat sedikit demi sedikit. Melakukan perubahan hanya pada satu aspek dalam proses pendidikan pada saat tertentu, membuat sedikit perbaikan disana sini. Sekarang dunia berubah dengan cepat dan diluar dugaan, karenanya strategi perbaikan sedikit demi sedikit tidak cukup. Ketika sistem tidak mempunyai atau tidak dapat menyesuaikan dengan perubahan, sistem itu harus memperbaiki dirinya - atau mati. Desain sistem memberikan alat untuk menciptakan seluruh sistem baru dan merencanakan strategi yang sesuai denga perubahan. 
Teknologi yang ketiga : Pengetahuan Kualitas

Pengetahuan kualitas adalah teknologi yang menghasilkan produk atau pelayanan yang memenuhi permintaan dan harapan pelanggan. Pengetahuan kualitas terdiri dari seperangkat pengetahuan dan prinsip matematika yang memungkinkan pengembangan proses yang kita laksanakan secara terus menerus, mendapatkan hasil yang baik dari investasi manusia atau sumber yang lainnya, dan "melaksanakan pekerjaan itu dengan baik pada setiap waktu". Pengetahuan kualitas telah menjadi alat yang sangat berharga dalam revolusi perubahan yang terjadi dalam perdagangan dan industri, tapi sangat sedikit digunakan dalam pendidikan. Ini merupakan salah satu komponen dari lima teknologi yang penting dalam merestrukturisasi sekolah yang berarti. Teknologi yang keempat : Manajemen Perubahan

Ketika orang mencoba menerapkan satu atau dua teknologi tanpa yang lainnya, banyak menghasilkan frustasi dan energi negatif. Energi negatif timbul ketika prang mencoba bekerja dan bertentangan dengan yang lainnya ( dimana $1+1=1 / 2$ ). Itu menyebabkan orang mengkritik yang lainnya, mencari politik, informasi bias, dan membela yang tidak semestinya. Orang biasanya menutup diri, karena meneruskan tingkah laku lama menjadi rintangan dalam upaya belajar sesuatu yang baru. Manajemen perubahan adalah jalan yang menuntun energi kreatif ke arah perubahan positif.

Teknologi yang kelima : Teknologi Instruksional

Teknologi instruksional sebenarnya terdiri atas dua bagian - alat-alat pembelajaran elekronik (komputer, jaringan komputer, multimedia, telekomunikasi) dan metode dan strategi desain instruksional yang amat penting untuk membuat alat-alat elektronik bekerja secara efektif. Alat-alat pembelajaran elektronik ini merubah dan terus akan merubah cara kita berkomunikasi dan belajar. Kita akan melihat suatu hari nanti gagasan siswa yang dikerjakan hanya dengan pencil, buku teks, dab kertas kerja ketinggalan zaman, usang dan kontraproduktif. Akan lebih baik, cepat, mudah dan murah untuk mendapatkan pengetahuan dan keahlilan.

Teknologi elektronik telah membuat perdagangan dan aktifitas pelayanan manusia menjadi produktif, perusahaan berorientasi pada pemuasan pelanggan, dan mereka mulai menjadi lebih kritis terhadap sekolah-sekolah. Tapi teknologi elektronik hanya dapat berkembang dalam bisnis atau sekolah yang organisasinya telah direkayasa ulang dengan pendekatan sistem yang prosesprosesnya dijalankan secara otomatis. Otomatisasi proses-proses yang lama menghasilkan 
prosedur yang ringkas, dan memberikan efek positif. Dengan demikian mengapa teknologi instruksional harus dipandang merupakan bagian strategi yang besar yang melibatkan empat teknologi yang lainnya dengan baik.

Seluruh dari kelima teknologi itu saling berhubungan pada beberapa tingkatan. Teknologi yang pertama (berpikir sistem) menunjukkan konsep umum dari sistem - pemikiran bahwa segala sesuatu berhubungan dan saling keterkaitan. Seperti akan kita lihat, berpikir sistem adalah perekat yang memegang segala sesuatu yang lain bersama. Empat teknologi yang lainnya diturunkan dari berpikir sistem :

$>$ Desain sistem adalah teknologi yang mendesain dan membangun sistem yang baru secara lengkap

$>$ Pengetahuan kualitas adalah aplikasi dari berpikir sistem untuk mengelola dan menghasilkan permasalahan hasil atau pelayanan yang memenuhi kepuasan pelanggan atau pemakai pada setiap waktu.

$>$ Manajemen perubahan adalah berpikir sistem yang digunakan pada aspek pengelolaan untuk menuntun inovasi dan perubahan.

> Teknologi instruksional adalah berpikir sistem yang digunakan dan pengajaran dan pembelajaran.

Bersama-sama, kelima teknologi ini mewakili banyak pemikiran dewasa ini dalam bidang desain organisasi, pembelajaran, pengajaran dan manajemen.

\section{DEFINISI TEKNOLOGI}

Nampaknya aneh menunjuk lima bidang di atas sebagai "teknologi”. Kebanyakan orang kemungkinan berpikir "teknologi" hanya sebatas mesin atau peralatan elektronik yang dipasang di dinding. Tapi definisi resmi dari teknologi adalah "penerapan pengetahuan yang sistematis atau pengetahuan yang diorganisasi untuk kegiatan-kegiatan praktis.” Dengan kata lain, ketika kita mengembangkan produk baru atau pembaharuan, disiplin, praktek, prosedur, alat, dan teknik yang berkumpul untuk membentuk inovasi baru disebut teknologi. Meskipun kita cenderung berpikir teknologi sebagai mesin yang menghasilkan inovasi baru atau produk, mesin itu sendiri tidak lebih penting dari pengetahuan, praktek, prosedur dan teknik yang berangkat dari perencanaan dan desain produk untuk pertama kalinya. Kombinasi dari berbagai disiplin ilmu yang terlibat menghasilkan produk sama halnya dengan mesin yang digunakan. 
Lima teknologi, adalah lima disiplin yang esensial yang harus berkumpul untuk memecahkan masalah dalam dunia pendidikan. Secara bersama-sama, kelima teknologi meliputi kommbinasi dari alat, mesin, peralatan elektronik, orang, proses dan kemampuan manajemen yang dibutuhkan dalam restrukturisasi sekolah yang efektif. Lima teknologi menekankan bahwa kekuatan dalam perubahan sekolah yang efektif tidak dalam bentuk perangkat keras baru atau peralatan elektronik (meskipun hal ini merupakan bagian yang penting). Namun, hal itu memerlukan kombinasi kemampuan intelektual, keahlian manajemen, proses dan alat-alat baru yang terkait dengan lima teknologi yang menyediakan kekuatan untuk terjadi perubahan yang efektif.

\section{SEBUAH ANSAMBEL DARI TEKNOLOGI}

Kelima teknologi harus dilihat sebagai sebuah ansambel (kelompok bermain musik yang bermain secara tetap) daripada sebagai sesuatu yang terpisah. Masing-masing dari teknologi ini betul-betul efektif ketika digunakan saling berhubungan satu dengan lainnya. Dalam cara yang sama bahwa peralatan musik ansambel telah dipilih untuk menghasilkan musik yang memikat, kelima teknologi secara totalitas saling melengkapi dan saling keterkaitan. Instrumen musik individual yang dimainkan sendirian, tanpa diiringi yang lainnya, menghasilkan sesuatu dengan efek tidak total. Dengan cara yang sama, kelima teknologi, jika diterapkan secara terpisah, menghasilkan hanya sedikit, pengaruh yang terpisah. Kekuatan untuk perubahan positif datang melalui kekuatan dan aksi yang utuh dan saling melengkapi.

Peter Sange, dalam bukunya TheFifth Discipline, menggunakan contoh pesawat DC-3 untuk menunjukkan bagaimana teknologi yang berbeda dibutuhkan untuk menghasilkan inovasi yang besar. Untuk menghasilkan pesawat terbang membutuhkan kombinasi dari fisika, metalurgi, kimia, kelistrikan, proses pembuatan, teknik manejemen, pelatihan teknik, kualitas kontrol dan teknologi yang lainnya. Teknologi-teknologi ini mungkin datang dari pengembangan yang terpisah dalam berbagai disiplin ilmu, tetapi untuk tujuan inovasi mereka menjadi "sebuah ansambel teknologi yang saling melengkapi satu dengan yang lainnya untuk mencapai kesuksesan.

Penerapan kelima teknologi secara bersama-sama dalam satu waktu terasa sulit, lebih mudah menggunakan peralatan baru secara terpisah-pisah. Pengintegrasian berbagai macam teknologi secara menyeluruh membutuhkan disiplin ilmu dan penuntun secara hati-hati. Tapi kombinasi dari berbagai peralatan akan menghasilkan hasil yang memuaskan. Kelima teknologi 
akan mecapai kekuatan yang besar hanya bila mereka bekerja bersama-sama. Jika kita menggunakan satu atau dua dari teknologi-teknologi ini pada satu waktu, belum menggunakan yang lainnya, seperti bermain kartu tanpa sempurna. Tanpa kelima teknologi, kita tidak akan mempunyai bagian yang penting yang akan menghantarkan sesuatu kepada hasil yang menyeluruh.

\section{HUBUNGAN SINERGIS DARI LIMA TEKNOLOGI}

Kata "sinergi" menjelaskan hubungan yang dinamis, saling keterkaitan yang nyata dari kelima tekonologi. Sinergi menunjukkan hubungan yang dibangun antara satu dengan lainnya. Jika kita merujuk kamus, kita menemukan kata berikut untuk kata sinergi : "Aktifitas bersama dari bagian-bagian yang berlainan sehingga mmenghasilkan pengaruh yang menyeluruh sehingga lebih besar daripada jumlah dua atau lebih pengaruh secara terpisah. "Secara sederhana, kita mempunyai sinergi ketika dua atau lebih benda menghasilkan pengaruh yang tidak menghasilkan kecuali mereka bekerja bersama-sama.

Dalam hubungan sinergis, $1+1$ lebih besar dari 2. Dalam penyatuan yang sinergis dari kelima teknologi, $1+1+1+1+1+1$ lebih besar dari 5. Dengan bekerja secara harmonis, mereka menghasilkan pengaruh yang lebih mempunyai kekuatan daripada mereka menghasilkannya secara sendiri-sendiri. Sinergis, adalah lawan dari antagonis, dimana individu bekerja bagian demi bagian dalam pertentangan, atau bertentangan satu dengan lainnya.

Beberapa orang telah mencoba menerapkan salah satu teknologi itu dalam pendidikan tanpa menggunakan empat teknologi yang lainnya. Hal ini sebenarnya jauh dari harapan. Masingmasing dari kelima teknologi ini membutuhkan pengaruh dari yang lainnya untuk dapat bekerja secara baik. Berpikir sistem memberikan kemampuan untuk menggambarkan bagaimana sesuatu bekerja bersama-sama untuk menhasilkan pengaruh secara pengaruh. Desain sistem menyediakan proses untuk menciptakan organisasi, program dan cara atau proses yang baru. Pengetahuan kualitas memfokuskan sistem pada pelanggan dan secara konsisten menghasilkan tingkat kualitas yang telah ditetapkan sebelumnya. Manajemen perubahan memberikan kemampuan menerapkan dan mengadakan perubahan dalam skala besar. Teknologi instruksional menerapkan apa yang kita ketahui tentang belajar, mengajar, penilaian dan media pembelajaran. Untuk mencapai potensi individual, masing-masing teknologi membutuhkan kekuatan yang disediakan oleh empat teknologi yang lainnya. Kalau tidak dari kelima teknologi itu ada dan bekerja bersama-sama secara harmonis, teknologi itu secara sendiri-sendiri menjadi bagian yang terpisah-pisah. 
Komponen penting dalam restrukturisasi sekolah adalah melihat bagaimana kelima teknologi itu mempunyai kekuatan saling berhubungan dan bekerja bersama-sama. Kegiatan yang terintegrasi dari kelimanya memerlukan keseluruhan manajeman dan panduan yang baik.

Kelima teknologi itu seperti pesulap, anda harus tetap memelihara semuanya di udara dalam waktu yang bersamaan. Sulap membutuhkan banyak ketangkasan atau ketarampilan tangan. Menyulap kelima teknologi membutuhkan sejumlah ketangkasan manajeman yang sesuaimanipulasi secara terus menerus dari kelima teknologi untuk mencapai tujuan akhir. Ini merupakan tantangan bagi pemimpin pendidikan dan para pengembang di masa yang akan datang.

Dalam banyak oganisasi, keberadaan individual, kelompok dan saling tekan organisasi akan menjadi penghalang kesusksesan dalam upaya mengadakan perubahan. Kekuatan yang mendorong perubahan dan pengembangan menunjuk kepada "kekuatan mengendalikan". Kekuatan yang saling bertentangan, bekerja berlawanan dengan kekuatan mengendalikan dan pergerakan yang menahan adalah kekuatan untuk dikendalikan.

Kekuatan yang harus dikendalikan adalah memaksakan dan memelihara status quo. Sering kekuatan itu bersifat negatif, emosional, tidak logis, tidak sadar dan berdasar pada keinginan memelihara hubungan dan struktur sosial yang sedang berlangsung. Kekuatan mengendalikan umumnya positif, beralasan, logis, sadar dan didasarkan pada keuntungan dan kepentingan ekonomi. Keduanya merupakan pasangan kekuatan yang harus diperhitungkan ketika melaksanakan restrukturisasi sekolah.

Masing-masing dari lima teknologi mewakili kekuatan pengendalian. Menerapkan salah satu dari kelimanya mungkin membawa hasil - sebentar. Tapi, pada akhirnya kekuatan pengendalian akan melawan efek positip. Itu seperti menyuntikan zat dari luar ke dalam tubuh manusia. Sistem kekebalan tubuh pada akhirnya melawan dan membuang zat dari luar, dan sesuatunya kembali normal. Tapi ketika kita melaksanakan seluruh dari kelima komponen teknologi secara simultan, kita membuat lingkungan dimana kebanyakan lingkungan menolak. 


\section{BAB II \\ BERPIKIR SISTEM}

Sebagai seorang pelajar muda di universitas, saya cenderung berpikir tentang masalah dengan cara yang sederhana. Pemecahan "masalah pendidikan" nampakya sederhana - menggaji guru dengan lebih baik dan membuat kelas semakin kecil. Saya belakangan sampai pada kesimpulan, karena saya mempelajari sistem dan berpikir sistem, bahwa permasalahan itu sangat komplek. Banyak solusi ditujukan hanya pada bagian-bagian tertentu saja dari masalah dan karenanya mempunyai pengaruh sedikit. Saya sekarang percaya bahwa pendidikan hanya bisa diperbaiki jika dipandang melalaui sistem lensa.

Sistem lensa ini memungkinkan kita melihat sesuatu dari tempat yang berbeda dimana seseorang melihat permasalahan yang sama dari lensa yang lain. Noreood Russel Hanson, dalam bukunya tentang metode sains, menyatakan bahwa orang sering melihat sesuatu yang sama tapi interpretasinya berbeda didasarkan atas pikirannya. Dia memberikan contoh berikut : Bayangan Johannes Kepler, astronom, melihat fajar dari atas bukit. Dengannya ada sorang teman astronom Tycho Brahe,. Kepler percaya bahwa bumi mengelilingi matahari. Brahe percaya matahari mengelilingi bumi. Keduanya melihat dalam waktu yang sama (saat pajar tiba). Bagaimanapun, Kepler melihat rotasi bumi secara perlahan mengitari matahari yang diam. Brahe, pada sisi lain, melihat matahari terbit mengitari bumi yang diam. Kebenaran adalah interpretasi seseorang yang melihat sesuatu berlainan, tergantung atas pemikiran dan kepercayaan mereka.

Jika kita melihat pendidikan tanpa sitem lensa, kita jatuh pada perangkap yang sama seperti pepatah orang buta yang diberikan tugas mendeskripsikan gajah. Ketika banyak orang mendengar cerita ini, mereka mungkin gagal menyadari bahwa bagian menarik dari cerita ini bukan pada masing-masing orang butanya, setelah memeriksa bagian yang berbeda dari bagian tubuh gajah, mempunyai pengertian yang berbeda apa yang ia jelaskan. Bagian menariknya adalah ketika seseorang (orang yang bercerita) bisa melihat seluruh sistem yang ada pada gajah dan memperhatikan bagaimana bodohnya seorang yang buta. Berpikir sistem adalah tangga yang memungkinkan kita memanjat tempat yang menguntungkan dimana kita bisa melihat keseluruhan sistem. Berfikir sistem memungkinkan kita melilhat pendidikan dengan kedepan, membuka perencanaan dasarnya, mmemungkinkan semua dilihat melalui pola dan opoerasional secara 
keseluruhan. Itu memungkinkan kita melihat bagaimana satu bagian masalah dalam proses pendidikan mungkin memberikan kontribusi pada masalah pada bagian yang lain.

\section{TEKNOLOGI PERTAMA}

Tekonologi pertama adalah berfikir sistem. Lebih dari dua dekade berpikir sistem telah berkembang dari dari dasar pengetahuan teoritis kedalam peralatan, prosedur dan teknik. Ada seribu literatur buku dan paper dikeluarkan dari akademik dan komunitas bisnis yang menunjukkan bagaimana berfikir sisttem dapat efektif diaplikasikan dalam pemecahan masalah dalam organisasi dan bagaimana ia dapat digunakan memajukan pembelajaran organisasi. Berfikir sistem dapat disebut teknologi dalam perasaan yang membentuk disiplin yang rasional dalam berfikir sesuatu dan pemecahan permasalahan manusia.

Seperti ditunjukkan pada bab I, seluruhnya dari kelima teknologi yang didiskusikan dalam buku ini diambil dari berfikir sistem. Berfikir sistem adalah benih dimana keempat teknologi yang lainnya tumbuh. Tanpa orientasi berfikir sistem, kita akan jatuh terperangkap dalam melihat kelima teknologi itu sebagai sesuatu yang terpisah dan tidak berhubungan. Berfikir sistem adalah lensa yang memfokuskan teknologi yang lainnya ke dalam kekuatan penuh ke dalam perubahan. Itu memungkinkan kita dapat menjelaskan mengapa kelima teknologi mendapat kekuatan yang lebih besar ketika mereka bekerja bersama-sama.

Berfikir sistem mengenal bahwa tidak ada aksi yang satu sisi memberikan pengaruh. Ketika kita berpindah dari satu unsur sistem, kita tahu bahwa kita akan dipengaruhi, pada tingkat yang berbeda, dari unsur yang lain dimana sistem berada. Berfikir sistem mengenalnya dan berffikir kembali bahwa kita harus berfikir dinamis, berubah secara alamiah.

Berfikir sistem adalah disiplin untuk melihat secara menyeluruh. Itu memberikan motivasi kita untuk berfikir tentang seluruh elemen dan hubungan yang ada dalam sebuah sistem, dan itu menunjukkan bagaimana strukturnya saling berhubungan secara efisien dan efektif. Dalam pendidikan, kita melakukan berfikir sistem ketika kita melihat pendidikan sebagai keseluruhan sistem daripada melihat nya sebagai aktifitas bagian secara terpisah-pisah. Biasanya, kita mempelajari pendidikan aebagai perangkat yang terpisah dan aktifitas yang berbeda- administasi sekolah, praktek kelas, kurikulum, pembelajaran, perkembangan siswa, penilaian, kebijakan, pendanaan dan lain-lain. Ini seperti berpikir variasi sistem yang membentuk tubuh manusia (sistem respirasi, sistem pencernaan dan lain-lain) hanya terpisah, sistem individu dan tidak berfikir 
bagaimana mereka bekerja bersama-sama dan tergantung satu dengan lainnya. Pendekatan terpisah dalam berfikir tentang pendidikan menghasilkan pengelompokan, tidak terintegrasi dan dicirikan dengan bagaimana pendidikan sebagai keseluruhan sistem. Tanpa berfikir sistem, kita hanya bisa "mengetahui bagian tepi". Kita seharusnya tidak terkejut, oleh karenanya, menemukan bahwa pekerjaan kita menghasilkan sedikit perkembangan. Untuk membuat kemajuan yang lebih dramatis, kita harus dapat mengerti interaksi satu sama lain dan kedinamisan komplek dari keseluruhan sistem, dan mendesain strategi untuk ikut campur dalam keseluruhan sistem.

\section{BERFIKIR SISTEM DAN PENDIDIKAN}

Sain klasik selama lebih dari tiga ratus tahun mencoba mengerti permasalahan baru dengan mengambil mereka secara terpisah dan kemudian mencoba mengerti keseluruhan dengan memperlajari karakteristik bagian-bagian. Orientasi ini kearah mereduksi sesuatu yang kompleks menjadi lebih sederhana, namun sering menghasilkan permasalahan yang jauh dari sederhana. Cara berfikir seperti ini sering dapat memberrikan pengertian tentang karakteristik interaksi antar bagian-bagian. Pada dekade terakhir, kita sampai pada kenyataan bahwa analisis ini, metode reduksi harus dilengkapi dengan sintesis dan pendekatan berfikir sistem yang mengarahkan kita mengerti lebih banyak dan lebih menyeluruh.

Tanpa mengerti secara umum tentang sistem alamiah sekolah, pendidik akan terus menerus melihat bagian demi bagian. Perbaikan sedikit demi sedikit adalah sesuatu seperti memberikan workshop guru, melengkapi peralatan, perubahan label dalam sekolah, revisi kurikulum, periode waktu di kelas dan pengajuan sejenis lainnya. Beberapa ajuan dan program mungkin sangat baik, tapi jika dijalankan sendirian, tanpa analisis yang rinci dan memikirkan bagaimana merreka berinteraksi dengan yang lainnya, mereka akan mempunyai sedikit pengaruh yang baik. Kita tidak hanya harus melihat faktor di dalam sekolah, kita juga harus melihat faktor-faktor yang mempengaruhi keseluruhan sistem dari luar.

\section{KONSEP UMUM}

Disini beberapa definisi umum konsep berfikir sistem. Masing-masing konsep sistem ini mempunyai definisi teknis. Saya mencoba menunjukkan semua dengan bahasa umum dan pada beberapa kasus, diberikan contoh dari pendidikan untuk menunjukkan bagaimana mereka diaplikasikan. 


\section{Sistem}

Sistem adalah kesatuan dari bagian-bagian atau komponen yang bekerja bersama sebagai kesatuan unit fungsional. Bagian-bagian dari sistem adalah pokok untuk perencanaan umum dan mencapai tujuan. Karena bagian-bagian itu bekerja bersama-sama sebagai kesatuan unit, sistem mempunyai karakteristik dan sifat tersendiri yang lebih dibandingkan gabungan dari masing-masing bagian. Kualitas dan sifat masing-masing individu terletak dalam hubungannya dengan keseluruhan sistem. Masing-masing bagian hanya bisa dimengerti dengan melihat bagaimana fungsi dalam hubungannya dengan keseluruhan sistem.

Ada sistem yang secara alamiah ada di alam semesta - sistem cahaya, variasi ekosistem, sistem peredaran darah manusia. Sistem yang lain (seperti sistem pendidikan) dibuat oleh manusia untuk mencapai suatu tujuan. Sesuatu menjadi sistem ketika kelompok merencanakan dan menggunakan prosedur dalam membuat keputusan. Pemerintahan, pendidikan, pemeliharaan kesehatan, perdagangan dan organisasi sejenis itu dibangun berdasarkan tujuan. Orang dalam memilih sistem, organisasi, dan aktifitas lainnya supaya mencapai tujuan dimana organisasi itu dibuat.

\section{Sistemik}

Sesuatu merupakan bagian dari sistem yang besar. Sesuatu itu komplek. Sesuatu itu berhubungan. Apa yang dikerjakan satu bagian dari sistem berpengaruh pada semua bagian. Kita tidak bisa membuang satu bagian dari sistem tanpa merubah kekuatan yang lainnya. Bagian-bagian secara dinamis saling berhubungan dan tidak bisa diisolasi dari yang lainnya. Optimalisasi satu bagian dari sistem tidak berguna untuk mencegah kegagalan seluruh sistem. Pemecahan sistemik adalah jangka panjang dan menyeluruh.

\section{Berpikir sistem}

Berpikir sistem adalah cara kita berpikir tentang permasalahan; cara kita mengenal dunia; cara kita menguraikan dan menjelaskan masalah. Untuk menerapkan berpikir sistem dalam permasalahan artinya bahwa kita berpikir masalah sebagai suatu sistem. Kita bisa mengerti dan menjelaskan sistem ; kita menyadari bahwa disana mungkin bukan satu penyebab dari permasalahan. 
Sistem terbuka dan sistem tertutup

Tidak ada sistem yang bekerja dalam ruang yang hampa. Fungsi semua sistem berinteraksi pada beberapa tingkat, dengan sesuatu di sekitarnya. Sistem tertutup adalah sistem yang hanya dibatasi dan dikontrol secara ketat interaksi dengan lingkungannya. Sistem terbuka, di sisi lain, mempunyai interaksi yang efektif dengan lingkungannya. Perubahan dalam lingkungan memberin pengaruh kepada kerja sistem. Juga, sistem memberikan pengaruh kepada lingkungannya, jadi ada pengaruh dua arah. Kita akan berpikir sistem pendidikan umum sekarang adalah sistem terbuka memberikan kontribusi yang luas dan tergantung pada kontribusi dari masyarakat.

Pembatas Sistem

Setiap sistem mempunyai pembatas yang membatasi dan menentukan sistem itu sendiri dan seperangkat bagian dari yang lain disekitarnya. Seperti disebutkan di atas, sistem yang keseluruhannya terbuka, tidak ada batas, tidak berinteraksi dengan tertib dengan sekitarnya bukan sistem secara keseluruhan. Itu hanya merupakan aktifitas yang sporadis. Keadaan pembatas sistem adalah persoalan menentukan apa jenis input sistem yang diterima dan keluaran apa yang akan dihasilkan. Dalam pendidikan, melibatkan jawaban atas pertanyaan seperti : Akankah sekolah mencoba mendidik siswa dengan tantangan yang keras, anak yang secara emosional terganggu atau kasar? Akankan sekolah mencoba menangani kesehatan siswa, keluarga, makanan dan masalah ekonomi seperti isu yang sangat kental dalam pendidikan ? Dalam pendidikan, menetapkan batas sistem selalu merupakan persoalan pertimbangan. Menentukan batas sistem adalah isu yang penting dalam sistem. Sistem harus mengatur masukannya, tapi itu dikerjakan tidak terlalu berlebihan atau akan mengancam relevansinya dengan linkungannya.

\section{Homeostatis (Kecenderungan menolak perubahan)}

Sistem mempunyai tendensi menolak perubahan sebagaimana sistem kekebalan tubuh menolak benda asing. Karakteristik sistem ini menunjukkan homeostatis - kecenderungan sistem untuk kembali ke keadaan semula dari keseimbangan setelah dipengaruhi oleh kekuatan luar. Dengan kata lain, ketika perubahan masuk ke dalam sebuah sistem, sistem akan selalu bekerja merubah ke keadaan semula. Kecenderungan sistem ini menjelaskan bagaimana sulitnya membuat perubahan yang sungguh-sungguh dalam sistem pendidikan masyarakat-mengapa banyak inovasi 
dan pengaruh melewati tempat yang terisolasi. Jika kita ingin mempunyai pengaruh yang besar, kita harus merencanakan banyak cara untuk melawan kekuatan yang akan mendesak perubahan sistem kembali ke keadaan semula. Teknologi yang keempat (Manajemen Perubahan) menyediakan cara mendesain untuk potensi kekuatan ke arah perubahan yang produktif.

\section{Detail Kompleksitas dan Kompleksitas Dinamis}

Istilah detail kompleksitas dan kompleksitas dinamis membantu menjelaskan kekomplekan alamiah sebuah sistem. Bererapa sistem komplek dalam hal banyaknya variabel yang terlibat. Ini disebut detail kompleksitas. Kompleksitas dinamis muncul karena penyebab dan pengaruh yang dipisahkan oleh waktu, tempat dan tidak kentara. Sulit menjelaskan apa pengaruh aksi dan apa hasilnya. Dalam pendidikan, kita mempunyai keduanya. Detail kompleksitas mengarah kepada keragaman masyarakat dan siswa yang terlibat, dan juga banyak sekali kegiatan, metode, isu, kebijakan dan hukum yang merupakan bagian dari sistem. Kita mempunyai kompleksitas yang dinamis karena kita tidak tahu aksi apa yang secara langsung berpengaruh terhadap hasil. Berhadapan dengan kompleksitas yang dinamis membutuhkan analisis yang cermat dalam hubungan antara aksi dan hasil. Teknologi ketiga (Pengetahuan Kualitas) menyediakan alat atau cara yang membantu mengarahkan analisis dan pemahaman tentang dinamis kompleksitas yang terlibat.

\section{Pengungkit}

Berpikir sistem mengajar solusi yang jelas umumnya bukan bekerja. Solusi jelas pada umumnya menciptakan peningkatan kecil/sedikit sebab mereka memusatkan hanya pada permukaan tingkat masalah, dan mereka sering menciptakan efek dalam jangka waktu pendek. Perlakuan yang kecil sesuai dengan tempatnya dan berpikir sebuah sistem akan menghasilkan perubahan yang besar.

Sistem single-loop dan sistem double loop

Single-loop dan double loop adalah konsep yang melibatkan bentuk umpan balik sebuah sistem. Umpan balik adalah informasi tentang hasil akhir, dimana umpan balik bagi sistem sehingga sistem dapat merubah pekerjaannya jika hasil tidak sesuai dengan yang diharapkan. Untuk mengerti sistem single-loop dan double loop, berfikir lagi tentang sistem pemanas rumah 
dan pendingin udara. Alat pengatur panas secara terus menerus mengontrol perubahan lingkungan, menghidupkan pemanas ruangan, atau menghidupkan pendingin untuk menyejukan ruangan, didasarkan atas keadaan suhu ruangan. Karena sistem ini menjadi sistem double loop, alat pengatur panas harus dapat mengatur atau menyesuaikan sesuai dengan tujuannya. Dengan kata lain, dia dapat bertanya kepada dirinya sendiri, "Mengapa saya mengatur suhu tertentu?". Double loop sistem adalah satu dia dapat mengubah perkiraan yang mendasarinya, kebijakan, dan tujuan atas dasar informasi yang diterimanya. Kedua, menyediakan kemampuan memberikan umpan balik kepada sistem sehingga sistem dapat bertindak sesuai data yang ada.

Double loop sistem dibutuhkan manakala ada potensi perbedaan antara maksud atau tujuan dengan hasil. Single loop sistem mungkin efektif dan efisien mencapai suatu hasil, tapi disini tidak bisa mencapai seperti apa yang kita inginkan. Sistem pendidikan harus dilaksanakan dengan sistem double loop, daripada single-loop. Mereka harus dapat secara terus-menerus mengevaluasi hasil dan menyesuaikan dirinya jika hasilnya tidak sesuai dengan hasil yang diinginkan.

Pengaturan diri

Semua sistem diarahkan pada tujuan khusus. Dalam pendidikan, tujuan pendidikan adalah siswa. Tapi harapan khusu lebih lanjut berkaitan dengan perubahan dalam masyarakat, perubahan siswa dan keluarga ingin dan butuh, perubahan dalam dunia kerja, dan perubahan ekonomi. Juga, masukan yang diterima melalui perubahan sistem pendidikan. Jadi, sistem harus dapat beradaptasi dengan jenis perubahan. Itu mungkin ingin menghasilkan jenis baru dari keluaran dan hasil. Bagaimana sistem mengadakan perubahan dalam dirinya?

Ada dua cara sistem mengatur dirinya. Satu, adaptasi. Yang lain transformasi. Adaptasi adalah proses untuk memperbaiki kesalahan dan membuat modifikasi untuk membawa sistem mengikuti perubahan dalam lingkungannya. Adaptasi hanya berjalan jika perubahan dalam lingkungan relatif kecil. Transformasi harus digunakan dalam kasus dimana sistem lalai untuk beradaptasi dengan lingkungannya secara perlahan dan sekarang ada perbadaan yang besar dirinya dengan lingkungan. Transformasi melibatkan pemikiran ulang kebutuhan, tujuan, proses, dan keluaran dari sistem. Jika sistem menunggu terlalu lama untuk mulai beradaptasi dengan perubahan lingkungan dan penambahan permintaan, itu mungkin memerlukan penggantian oleh sistem yang seluruhnya baru, karena pengembangan sistem yang sudah ada tidak akan bekerja lama. Hal ini sangat baik dalam kasus sistem pendidikan saat ini. Karena sistem pendidikan telah menunggu terlalu lama untuk beradaptasi, mungkin harus seluruhnya diganti dengan mekanisme 
baru yang lebih sesuai dengan teknologi dan metode pembelajaran dari dunia modern. Beberapa mungkin tidak setuju, tapi menurut pandangan saya sistem pendidikan sekarang tidak cukup kuat merespon perubahan dunia dan teknologi yang 


\section{BAB III}

\section{ALAT-ALAT UNTUK BERPIKIR SISTEM}

Prinsip-prinsip dari berpikir sistem muncul dari sejumlah disiplin ilmu yang berbeda fisika, teknik, biologi, psikologi dan tingkah laku organisasi. Umumnya, bagaimanapun, semua disiplin ilmu mempunyai beberapa dasar alat-alat berfikir. Alat-alat ini didesain untuk menolong kita berfikir tentang dunia sekitar kita dengan cara yang lebih kompleks. Mereka menolong kita berfikir tentang sistem - yang mempunyai hubungan dan keterikatan yang luas satu dengan lainnya.

\section{SISTEM DIAGRAM}

Salah satu dari banyak alat untuk berfikir sistem adalah sistem diagram. Diagram menolong kita melihat siklus dari pengaruh-pengaruh yang ada dalam berbagai kegiatan atau pola. Peter Senge, dalam bukunya The Fifth Discipline (Doubleday,1990), memberikan beberapa contoh sederhana dari sistem diagram. Dia mulai dengan membuat diagram dalam aktifitas sederhana mengisi segelas air. Ketika kita mengisi gelas dengan air, kita sebenarnya menjalankan sistem pengaturan air sangat sederhana. Kita melihat kenaikan tingkat air dalam gelas yang kita isi. Kita terus mengontrol perbedaan antara air sekarang dengan tingkat air yang kita inginkan. Selama tinggi air naik, kita mengatur masukan air dengan mengatur posisi keran untuk lambat atau cepat untuk naiknya permukaan air, dan kita mematikan aliran ketika gelas penuh.

Hal penting yang dapat diambil dari sistem diagram adalah bahwa hal itu dapat menangkap seluruh cerita, tidak hanya bagian-bagiannya saja. Hal itu menunjukkan segala sesuatu yang terlibat dalam proses dan bagaimana satu aksi dipengaruhi oleh kegiatan lainnya dalam satu proses. Diagram sistem menolong kita lepas dari berfikir sesuatu hanya mempunyai satu sebab. Kita bisa melihat, sebagai contoh, dari diagram segelas air, bahwa posisi keran menyebabkan level air naik. Tapi hal lain yang juga benar bahwa tingkat air dipengaruhi oleh laju aliran dari keran.

Latihan yang sangat membangun dalam berfikir sistem adalah membentuk kelompok yang diberikan tugas untuk membuat diagram dalam situasi atau masalah yang dihadapi. Masalah motivasi siswa, rendahnya nilai matematika, masalah disiplin, kepuasaan pelanggan, atau masalah lainnya. Membentuk sistem diagram dari berbagai permasalahan, berfikir tentang berbagai macam faktor yang berpengaruh terhadap masalah. Dengan berpikir demikian, kita akan banyak 
menurunkan taktik pemecahan yang sulit dipercaya dibandingkan jika kita menggunakan pendekatan satu penyebab.

\section{PEMODELAN}

Berpikir sistem adalah tentang bagaimana sesuatu bekerja dan tentang membuat prediksi. Alat modeling atau diagram model menunjukkan perubahan hubungan diantara bagian-bagian dalam seluruh proses atau kegiatan. Menggambar model dari semua bagian menolong kita mengerti sistem alamiah yang kita tentukan. Cara yang baik belajar sistem modeling adalah mulai dengan latihan sederhana yang biasa kita lakukan, seperti memakai baju pada pagi hari. Ketika seseorang memutuskan baju apa yang akan mereka pakai tiap hari, disana ada berbagai faktor yang terlibat dalam keputusan (cuaca, peristiwa, suasana hati sendiri, jenis baju, manfaat dan lain sebagainya).

Menggunakan model seperti itu memungkinkan kita melihat bahwa permasalahan yang kita pikir sederhana, kenyataannya, melibatkan banyak faktor yang harus kita pikirkan sebelumnya. Menggambar sistem model demikian menambah pemahaman kita untuk permasalahan yang komplek dan memungkinkan kita melihat lebih jelas mengapa permasalahan itu ada dan bagaimana itu dipengaruhi. Sistem model menunjukkan pola pengulangan dan hubungan diantara bagian-bagian. Mereka alat yang berguna dalam menolong mengerti kekomplekan yang benar dari permasalahan atau situasi.

\section{STELLA II}

Minat menggunakan berpikir sistem terus tumbuh, sehingga kebutuhan alat-alat baru mendukung upaya ini. Salah satu alat berpikir sistem yang sangat luas digunakan adalah Stella. Stella adalah perangkat lunak yang dikembangkan komputer Macintosh. Dibuat untuk menolong orang membangun sistem diagram dan sistem model. 


\section{BAB 4}

\section{DESAIN SISTEM}

Disain sistem adalah penerapan berpikir sistem dalam proses desain. Ketika kita berpikir desain, kita biasanya berpikir mendesain produk atau barang, rumah, atau gedung perkantoran. Ketika kita mendesain sistem, kita mendesain struktur dimana manusia, proses, alat dan mesin dikombinasikan untuk mencapai tujuan yang telah ditentukan. Desain sistem meliputi perencanaan waktu, uang, dan sumber daya manusia; mendesain fasilitas, proses, aliran material, dan merencanakan semua aktifitas lain yang bekerja bersama untuk mencapai tujuan dimana sistem menginginkannya.

Mendesain sistem baru berbeda dari memperbaiki atau mengembangkan sistem yang sudah ada. Jika anda berfikir anda dalam pekerjaan memperbaiki sesuatu, kemudian anda menerima struktur yang sudah ada dan berkata :'Baiklah, saya akan menerima itu seperti yang sudah ada, tapi mari kita harus melakukan dua hal penting untuk menjadi lebih baik". Dalam memperbaiki sesuatu, kita mulai dengan struktir yang ada dan berangkat dari sana. Desain berbeda karena, ketika kita mendesain, kita mulai dengan visi sistem yang ideal dan kita membuat jenis baru secara keseluruhan dari struktur organisasi untuk mencapai misi yang sistem baru inginkan.

Mendesain sistem pendidikan baru berhadapan dengan urusan mengganti sistem persekolahan sekarang dengan sesuatu yang berpotensi cukup berbeda - bukan memperbaiki apa yang ada sekarang. Oleh karena itu, kita berkata :"Mari kita hapus asumsi kita dari sistem yang ada dan menggantinya dengan asumsi yang lebih lekat menghadirkan apa yang kita tahu tentang bagaimana siswa belajar, tentang metode instruksional, tentang kualitas, insentif, dan tentang metode manajemen modern." Jika kita berpikir sekolah diorganisasikan, diadministrasikan, dan didanai seperti sekarang, kita terbatas pada pemikiran kita tentang sekolah yang sudah ada. Kita kemungkinan berpikir hanya pada ide seperti itu yang bisa berjalan dalam keterbatasan sekolah yang ada sekarang dan sistem birokratik. Bagaimanapun, jika kita berpikir tentang pendidikan sebagai penciptaan pelayanan pendidikan yang menyediakan siswa dan keluarganya, keseluruhannya baru dan kemungkinan terbuka untuk mereka. Kita sekarang bisa mempunyai daya cipta dan berpikir cara mengatur sumber daya, metode, orang, bangunan, dan alat teknologi untuk kemajuan pendidikan. Sekolah dalam sekolah menjadi mungkin. Pembelajaran di rumah atau tempat lain dalam lingkungan bisa. Sekolah sewaan, beasiswa untuk sekolah swasta, atau sekolah di luar ruangan bisa dipertimbangkan. Kita dapat mendesain kurikulum yang dapat digunakan 24 
jam sehari melalui media elektronik. Sekolah mungkin dapat dengan tutor sebaya, kerja dalam kelompok kecil, pembelajaran kooperatif diantara siswa bekerja dengan proyek penelitian,, dan pembelajaran laboratorium dengan teknologi tinggi sebagai lawan dari pembelajaran kelas dan sajian guru satu arah. Desain adalah kategori aktifitas yang diketahui sebagai teleologikal. Kata ini berasal dari Yunani telos, artinya akhir dan menyampaikan ide tentang sesuatu yang bisa mengarahkan langsung pada akhir atau bentuk kebutuhan. Dalam hal ini, desain sama dengan perencanaan, pembangunan, dan perekayasaan. Semua aktifitas di alam adalah teleologikal sebab mereka langsung berfikir dan bekerja ke arah mencapai tujuan. Desain adalah berpikir sesuatu dan membuat alternatif pemecahan supaya keluaran yang menjadi alternatif akan lebih efektf dan efisien mengarah ke tujuan yang ditentukan atau outcome.

Sebagai ilustrasi, andaikata tujuan kita adalah memecahkan masalah pendidikan. Kita mungkin mulai dengan menganalisis sistem yang ada, mengidentifikasi berbagai hal atau situasi dimana sistem sistem sekarang tidak dapat bekerja secara efektif, dan kemudian usulan pemecahan untuk situasi itu. Apakah anda melihat bahwa pendekatan yang dijelaskan bukan sebuah desain sistem? Itu bukan desain sebab kita mulai dengan menggunakan sistem yang ada sebagai titik tolak. Dalam desain sistem kita mulai dengan penentuan yang cermat tentang formulasi tujuan dan misi pendidikan dan kemudian bekerja kembali dari sana untuk membuat visi dari sistem yang mungkin didesain untuk membentuk fungsi-fungsi penting untuk mencapai tujuan.

Mulai dengan apa yang sudah ada dan mencoba memperbaikinya biasanya meuntun kepada pemecahan yang sepotong-sepotong, tidak saling berhubungan dan terpisah-pisah. Jenis penyelesaian ini tepat jika sistem tidak terlalu jauh keluar dari misinya. Tapi ketika sistem keluar dari lingkungannya, ketika ia mencapai titik yang terlalu jauh untuk mencapai tujuan, kita membutuhkan desain sistem yang berbeda. Perbaikan kecil dalam sistem sekarang terasa mudah tapi tidak akan membawa suatu hasil yang menyeluruh apa yang kita inginkan. Desain adalah sukar untuk dirasakan, tapi desain akan memungkinkan keuntungan besar dari segi hasil.

\section{TIFE BARU ORGANISASI}

Untuk mencapai penambahan yang berati dalam produktifitas siswa, akan penting untuk mendesain tife organisasi yang total baru untuk pembelajaran - organisasi yang menyimpang jauh dari struktur organisasi yang ada. Mengapa harus organisasi baru yang berbeda dari struktur yang ada? Penyebabnya adalah : 
Struktur sekolah sekarang didesain sebelum manajemen modern dan metode instruksional yang kita ketahui sekarang ditemukan.

$>$ Struktur organisasi baru akan berbeda dengan sekarang satu diantaranya organisasi sekolah sekarang didesain seputar guru dan mengajar dibandingkan dengan siswa dan pembelajaran

$>$ Struktur organisasi baru lebih mampu dalam teknologi yang dapat digunakan dalam perkembangan yang besar dalam prosedur instruksional, informasi yang didapat dan metode pembelajaran.

$>$ Perkembangan masyarakat terutama pergesran masyarakat industri ke masyarakat informasi membutuhkan jenis baru organisasi.

\section{MENGAPA DESAIN ITU PERLU}

Dengan menggunakan berpikir sistem untuk melihat reformasi pendidikan, kita melihat bagaimana berbagai upaya peningkatan dan perubahan pada dasawarsa terakhir terasa jauh dari harapan. Memperpanjang hari sekolah dalam setahun, membuat kelas semakin kecil, menawarkan pelajaran yang berat, meletakkan komputer di kelas, memasang laboratorium komputer, contoh sekolah yang didanai telah menghasilkan sedikit perkembangan. Ini disebabkan kebanyakan dari peningkatan dan reformasi itu hanya perbaikan kecil pada praktek masa lalu. Pandangan saya dalam proses pendidikan masih terikat pada batas tradisi lama dalam cara kita berfikir. Persepsi yang sudah ketinggalan zaman menghalangi perkembangan cara berpikir baru tentang organisasi yang didesain untuk memajukan dan membatu perkembangan pembelajaran.

\section{PANDANGAN KEDALAM LAWAN PANDANGAN KELUAR}

Upaya perbaikan pendidikan lebih dari dua dasawarsa terakhir tetap pada permasalahan dan kekurangan dari permasalahan pendidikan sekarang. Individu atau kelompok yang berfikir perbaikan sering melihat sistem dari dalam ( daripada melihat dari luar, melalui berfikir sistem lensa). Bagian dalam ini terbatas pandangan yang membawa mereka kepada pertanyaan seperti :

$>$ Apa yang salah dengan sistem ?

$>$ Bagaimana mengembangkannya?

$>$ Bagaimana meningkatkan kemampuan guru ?

$>$ Bagaimana lebih fokus kepada basic ?

$>$ Bagaimana meningkatkan keterlibatan orang tua dan masyarakat? 
Pertanyaan berdasarkan pandangan dari dalam ini mendorong cara berpikir pandangan dari dalam. Tife pertanyaan seperti itu masuk akal ketika sistem hanya bertemu dengan sedikit tantangan. Tetapi akan terjadi kekacauan, ketika sistem berfungsi terlalu dibawah dari tingkat yang diinginkan, dan dimana terjadi jurang antara hasil yang dicapai dengan keinginan - saatnya untuk menggunakan pandangan luar dan bertanya dengan seperangkat pertanyaan yang berbeda :

Apa yang diinginkan oleh pelanggan kita (orang tua, siswa, pekerja, perguruan tinggi)?

$>$ Apa implikasi keinginan tersebut dengan dalam pendidikan ?

> Bagaimana kita memikirkan kembali agar pendidikan lebih baik dan bisa memenuhi keinginan dan kebutuhan pelanggan?

$>$ Bagaimana memunculkan image baru dari semuanya di atas yang bisa meuntun kepada desain yang seluruhnya baru dari pembelajaran?

$>$ Bagaimana kita menggunakan prinsip dan strategi desain sistem untuk membangun dan melaksanakan sistem baru?

Pertanyaan dengan pandangan luar ini cukup berbeda dengan pertanyaan yang dibentuk dengan pandangan dari dalam. Pertanyaan pandangan dalam memfokuskan pada pengembangan sistem yang telah ada, pertanyaan pandangan luar merubah fokus dari pengembangan sistem yang kita punya sekarang untuk memperluas kemungkinan sistem baru. Jika kita akan bertemu tantangan di depan dari era informasi dan teknologi, kita harus berhenti bertanya dengan pertanyaan pandangan dari dalam (dan berhenti mengembangkan sistem sekarang). Malahan, kita akan membutuhkan penggunaan desain sistem untuk mebangun sistem yang baru dan lebih efektif dalam pembelajaran dan pengajaran.

\section{DESAIN UNTUK PERFORMANSI MANUSIA}

Bagian desain sistem meliputi merancang peran pekerjaan yang bisa dilakukan dengan baik oleh orang yang akan bekerja dalam sistem. Sebuah organisasi tidak tergantung kepada tersedianya atau tidak adanya pekerja yang super-hero. Tujuannya membangun struktur organisasi semua keahlian normal pekerja mencapai hasil yang memuaskan. Hal ini dapat dilakukan dengan desain peran perkerjaan yang efektip, pelatihan yang efektip, dan menggunakan alat-alat yang dapat mempertinggi produktifitas dan kemampuan sistem komputerisasi, bentuk dan prosedur otomatis, dan perlengkapan kemampuan kerja seperti reference sheet, job aids, dan checklist. 


\section{PROSES MENDESAIN}

1. Mengenal dan menggambarkan tujuan desain

Menjelaskan tugas yang akan dicapai sistem baru dan jenis sistem yang ingin kita desain. Tujuan kita membangun sistem untuk mencapai tujuan yang telah ditetapkan. Apa tujuan yang ingin kita capai dan jenis sistem mana yang dibutuhkan untuk mencapainya?

2. Menjelaskan alasan untuk menggunakan desain

Kita menggunakan desain manakala kita setuju bahwa struktur yang ada tidak mampu mencapai tujuan yang diharapkan. Kebutuhan apa yang tidak dapat dicapai dengan sistem yang ada dan mengapa mengapa kita membutuhkan desain baru ? Jika modifikasi sedikit dari sistem sekarang memungkinkan sistem mancapai kebutuhan, kita tidak membutuhkan desain lain yang baru. Kita menggunakan desain ketika kita membutuhkan penyelesaian yang baru.

3. Menetapkan batas-batas desain

Batas menggambarkan ciri dan bagian-bagian perangkat sistem dalam lingkungannya. Untuk menentukan batas, kita mengidentifikasi kisaran aktifitas dan tujuan untuk sistem yang akan kita desain. Kita menginginkan gambaran batas yang cukup sempit sehingga sistem akan mempunyai kapasitas organisasi, kemampuan manusia, dan sumber keuangan yang cukup untuk memungkinkan mencapai tugas atau tujuan yang telah ditetapkan. Kita juga menentukan lingkungan yang di luar batasan untuk mengerti bagaimana sistem akan berinteraksi dengan lingkungan untuk memperoleh berbagai sumber daya yang dibutuhkan untuk berjalannya sistem dan melihat dengan cara berbeda dimana lingkungan menenttukan kesuksesan sistem.

4. Merumuskan ide inti, nilai dan gambaran dari sistem masa depan yang menuntun desain

Gagasan inti dasar dan nilai yang akan menuntun desain harus disetujui terlebih dahulu. Disini mungkin prinsip-prinsip seperti berikut : Desain akan fokus kepada siswa sebagai unsur kunci, desain akan mempertimbangkan permbaharuan dan perbaikan dan fokus pada kualitas, desain akan mungkin dilaksanakan dalam pendanaan yang terbatas atau prinsip-prinsip yang lainnya. Kita akan memutuskan jika nilai-nilai sistem efisien, efektf atau biaya yang cukup tinggi, apakah kita ingin memajukan inisiatip individu, kebebasan individu, pilihan dan respon orang tua, kompetisis pasar dan lainnya yang kita diskusikan. Kita juga membangun image atau gambaran dari sistem masa depan.

5. Menetapkan harapan, aspirasi, tujuan dan kebutuhan sistem yang didesain 
Tujuan desain telah ditetapkan pada langkah 1. Disini kita menetapkan lebih detail apa yang kita inginkan dari kerja sistem, siapa pelanggan sistem (siswa, orang tua, pembayar pajak, masyarkat bisnis dan lain-lain); pelayanan pendidikan harus menawarkannya pada mereka; karakteristik pelayanan harus dipunyai; dimana, kapan dan bagaimana pelayanan dikembangkan yang merupakan respon sistem kepada pelanggan, komunitas dan masyarkat luas. Bagaimana sistem berhubungan dengan berbagai tingkat pemerintahan, hubungan sistem dengan sistem yang lain (seperti kesehatan masyarakat, sistem hukum dll.)

6. Mnciptakan dan menaksir alternatif yang mewakili sistem masa depan

Dalam proses desain, kita ingin menciptakan beberapa alternatif desain, tidak hanya satu. Alternatif ini bisa diajukan pada peserta yang berbeda dengan pandangan yang beragam dengan reaksi dan masukan. Lebih mudah membuat dan menaksir desain alternatif ini daripada membangun dan menilai sistem alternatif.

7. Menentukan kriteria alternatif evaluasi

Sebelum mengajukan alternatif untuk evalusi dan masukan, kita harus mengidentifikasi kriteria yang digunakan dalam tahap evaluasi.

8. Menggunakan kriteria, memilih alternatif yang lebih baik

Tahap ini melibatkan diskusi yang serius dari alternatif dan keputusan akhir mengenai mana alternatif yang lebih memberi harapan atau kombinasi dari pemecahan alternatif. Idealnya perancang dan pelanggan yang mewakili harus berpartisipasi pada langkah ini.

9. Menggambarkan sistem masa depan

Kita sekarang menjelaskan sistem ke depan dengan hubungan komponen-komponennya. Penjelasan dalam sistem pendidikan meliputi penjelasan sub sistem manajemen; pembelajaran, kurikulum, dan sub sistem penilaian; subsistem manajemen siswa; subsistem evaluasi; dan lain sebagainya. Penjelasan ini mungkin menyerupai cetak biru, penjelasan teknis, rincian pekerjaan, buku pedoman dan buku petunjuk.

10. Merencanakan pengembangan sistem didasarkan atas penjelasannya

Dalam kenyataannya, kita merencanakan untuk pengembangan sistem dalam waktu yang sama ketika kita bekerja pada tahap akhir.

\section{STRATEGI DAN PENDEKATAN DESAIN}


Desain sistem bukan proses berdasarkan intuisi. Bukan aktifitas manusia yang secara alamiah didapat. Ada keahlian, pendekatan dan strategi untuk mendesain sistem yang dipelajari dan dipraktekan sebelum orang menjadi cakap dalam aktifitas ini. Ada dua strategi dan pendekatan desain sistem yaitu : desain ideal dan desain yang terjadi bersama-sama. Desain ideal didasarkan atas pandangan sebuah sistem ideal kemudian membentuknya, desain concurent dibangun atas kebersamaan seluruh komponen sistem.

\section{KOMPONEN-KOMPONEN SISTEM}

Salah satu tahapan penting dalam mendesain sistem adalah mengidentifikasi fungsi dan aktifitas yang berlangsung pada suatu tempat dalam sistem untuk mencapai seluruh tujuan. Saya akan menggunakan kata komponen yang menunjukkan fungsi, aktifitas dan unsur yang membangun sistem.

Untuk mengidentifikasi komponen dalam sistem pendidikan, kita harus berpikir tentang sistem dalam istilah berbagai jenis aktifitas yang dibentuk dalam sistem : kurikulum, pembelajaran, penilaian, manajemen, pembelanjaan, gaji pegawai, transportasi, pelatihan guru dan seterusnya yang merupakan contoh aktifitas yang berlangsung dalam sistem pendidikan. Pertama kali diperkirakan, komponen -komponen yang mewakili daftar dalam subsistem seperti yang terdapat dalam model sebelumnya : misi, kurikulum, pembelajaran, penilaian, operasi manajemen, logistik, dan lainnya. Dari subsistem kemudian dirinci komponen-komponenya.

\section{MISI}

Semua sistem yang didesain dengan baik diarahkan kepada tujuan khusus. Dalam pendidikan, tujuannya adalah, kiranya, pendidikan siswa. Tapi harapan khusus terjadinya perubahan dalam masyarakat, dunia kerja, dan ekonomi.

Misi mengarahkan seluruh penggunaan waktu, sumber daya fisik, dan orang. Setiap dolar yang dibelanjakan, atau manusia yang diberikan tugas, atau sumber daya fisik dikeluarkan, ada kesempatan hilang. Tujuan dari sub sistem misi adalah menjamin bahwa setiap dolar yang dibelanjakan, setiap tugas yang diberikan, dan semua sumber daya yang dikeluarkan memberikan kontribusi terhadap tujuan nyata. Kemampuan sistem seluruhnya harus diukur dan dievaluasi agar tercapai kesuksesan sesuai dengan misi yang ditetapkan. 


\section{MANAJEMEN OPERASIONAL}

Komponen manajemen operasional bertanggung jawab untuk mengatur sistem secara keseluruhan. Manajemen operasional juga harus menjamin bahwa perencanaan, aktifitas, dan fungsi bekerja sesuai dengan misi sistem. Jika tidak, harus ditentukan mengapa demikian. Fungsi ini disebut kontrol.

\section{PENELITIAN DAN PENGEMBANGAN}

Komponen penting lainnya adalah penelitian dan pengembangan. Penelitian secara sederhana diartikan memperoleh informasi mengenai apa yang bekerja dan apa yang tidak didasarkan pada pengukuran yang objektif dari hasil. Pengembangan diartikan menghasilkan atau mendesain material dan metode didasarkan pada pengetahun yang baik dari apa yang bekerja.

\section{INPUT, PROSES DAN OUTPUT}

Pemikir sistem telah menemukan pemikiran yang cukup bermanfaat dari sistem tentang istilah input, proses, dan output. Input adalah sesuatu seperti orang (siswa, pekerja), uang, dan sumber daya yang lainnya. Output adalah produk akhir dari sistem. Sistem pendidikan, sebagai contoh, menerima input berupa uang dan sumber daya yang lainnya. Input dirubah dalam bentuk bangunan, gaji guru dan para administrator, book, perlengkapan dan sebagainya. Sistem kemudian menghasilkan kecakapan dan pengetahuan siswa sebagai output. Sistem menghasilkan output dengan melaksanakan berbagai proses dan kegiatan. Proses adalah sesuatu seperti menyeleksi kurikulum, registrasi siswa, tes dan penentuan kelas, bimbingan siswa dan mengadakan pertemuan dengan orang tua.

Manajer sistem (sekolah, daerah atau administrator negara) mengambil keputusan bagaimana sumber daya (input) akan digunakan dan proses apa yang akan digunakan untuk menghasilkan proses. Mereka memutuskan, sebagai contoh, berapa banya dana yang akan dialokasikan untuk gaji dan personel, berapa banyak menggunakan untuk modal pembiayaan (gedung, perlengkapan, komputer dan sebagainya) dan mereka menyusun kebijakan untuk diperintahkan dalam proses atau prosedur yang merupakan bagian dari sistem. 
Ada seperangkat kondisi lain yang berhubungan tapi tidak dibawah pengontrolan seorang manajer, Bagian ini, dianggap sebagai hambatan dari sistem : keterbatasan sumber daya yang dapat digunakan, permintaan dunia usaha atau perguruan tinggi untuk karakteristik dan keahlian khusus dari output (lulusan), dan keterbatasan jenis guru dan pekerja lain yang tersedia yang berhubungan dengan sistem sekolah. Hambatan lingkungan adalah menentukan dan tidak dibawah kontrol dari manajer. Mereka harus dipertimbangkan sebagai bagian dari sistem yang lebih besar dimana sistem harus berjalan. Contoh dari elemen yang merupakan yang harus dipertimbangkan dalam lingkungan sekolah adalah keluarga, revolusi komputer, sistem politik, dan struktur pajak.

Output tidak harus hanya pada jumlah siswa yang lulus. Penilaian kita harus didasarkan pada kualitas dari lulusan dalam arti pengetahuan dan keahlian yang berguna yang mereka peroleh dan kesesuaian lulusan dengan dunia kerja dan perguruan tinggi.

Akhirnya, untuk menjadi sistem yang benar, kita harus menambahkan lingkaran umpan balik kepada diagram yang kita buat. Jika output dari sistem (siswa yang tamat) tidak memenuhi standar kualitas yang diharapkan, ini harus mengadakan penyesuaian atau adaptasi dalam proses sistem yang secara langsung mengarahkan siswa pada keterampilan atau pengetahuan yang kurang dari siswa.

\section{BAB V}

\section{ALAT-ALAT UNTUK MENDESAIN SISTEM}

Alat-alat untuk mendesain sistem menolong kita berpikir tentang berbagai fungsi dan komponen dari sistem ketika kita mendesain, dan memungkinkan kita secara efektif mengkomunikasikan ide kita kepada yang lainnya dalam sistem. Alat-alat yang dapat digunakan untuk mendesain sistem antara lain :

1. Model, diagram alir, dan diagram input-output

2. Future workshop, yang berguna untuk menemukan situasi permasalahan, menurunkan visi untuk masa depan dan mendiskusikan bagaimana visi dapat direalisasikan. Cara ini terdiri dari tiga tahapan yaitu : tahap kritikan, tahap khayalan, tahap implementasi.

3. Backward mapping, setelah menggambarkan desain yang ideal, langkah selanjutnya adalah proses backward mapping yang menolong kita mengidentifikasi fungsi tiap level dari sistem untuk mendukung desain yang ideal. 
4. Membangun konsensus diantara partisipan

5. Groupware dan Desain komputer

6. Simulasi Komputer 


\section{BAB 6}

\section{SAINS KUALITAS}

Sains kualitas adalah aplikasi berpikir sistem untuk memanage dan persoalan menghasilkan produk atau pelayanan yang memuaskan kebutuhan pelanggan pada setiap waktu. Akar dari sains kualitas adalah metode pengontrolan kualitas (quality control) yang dipergunakan

pada pabrik selama perang dunia II. Metode ini muncul bersamaan waktunya dan merupakan kombinasi dari berpikir sistem. Sains kualitas didasarkan atas pengetahuan teori sistem. Untuk mengerti sains kualitas, pertama-tama harus mengerti kerja organisasi sebagai sistem. Masingmasing bagian saling ketergantungan dan bersinergi.

Sekarang, kebanyakan bisnis, besar dan kecil, mengadopsi pendekatan sains kualitas dalam membangun bisnis. Pemerintah federal dan bagian mengenalkan istilah Total Quality Management (TMQ) (Manajemen Mutu Terpadu) dalam operasional sehari-hari.

\section{KONSEP DASAR}

Ide yang mendasari sains kualitas adalah kontrol kualitas (quality control) yang dirancang dalam setiap prosedur, kegiatan, langkah dari setiap langkah yang terjadi dalam organisasi. Daripada memeriksa kualitas pada akhir proses, kita harus secara rutin mengembangkan kegiatan dan langkah pada keseluruhan proses, sehingga menjamin hasil yang lebih baik pada setiap waktu. Kita harus selalu berusaha mengembangkan setiap proses yang dilakukan.

Ide-ide tersebut dapat dipecah kedalam proses yang fundamental (mendasar) dalam sains kualitas. Proses-proses ini meliputi integrasi manusia, bahan, metode dan mesin. Proses menghasilkan produk terdiri dari berbagai sub proses, prosedur, dan kegiatan. Dengan mempelajari setiap langkah, bahan, mesin dan kegiatan manusia yang terlibat dalam proses, kita akan secara terus menerus mengembangkan proses.

Jika sebuah sistem tidak menghasilkan hasil seperti yang telah diutarakan, itu dikarenakan proses tidak bekerja dengan baik atau kita telah memilih proses yang salah.

Pedekatan sains kualitas menuntut bahwa pekerjaan tidak dilakukan sembarangan. Pekerjaan itu memerlukan studi, analisis, dan dibahas secara ilmiah. Hal itu membutuhkan monitoring dan pengukuran semua proses di dalam organisasi apakah terjadi perbaikan dan memenuhi kebutuhan pelanggan. Observasi dan pengukuran ini menggunakan pedoman untuk 
mengambil keputusan tentang bagaimana mengembangkan kegiatan, proses dan prosedur yang digunakan manusia dalam organisasi.

Sains kualitas juga merupakan kunci untuk mengontrol biaya. Biaya dapat direduksi dengan mengganti dengan proses yang efisien daripada proses yang kurang efisien. Kita harus segera menghentikan pembiayaan keuangan pada setiap langkah, kegiatan atau proses yang kurang efektip dan mulai membelanjakan uang untuk menghasilkan hasil yang lebih baik

\section{VARIASI}

Untuk mengerti sains kualitas, pertama kita harus mengerti variasi. Variasi menunjukan fakta bahwa ada dan akan selalu ada perbedaan satu dengan lainnya. Dalam pendidikan, ada variasi diantara sekolah, buku-buku, peralatan, fasilitas fisik, temperatur dalam ruangan, tingkat gangguan dan keadaan lainnya. Manusia, tentunya berbeda dalam berbagai hal. Mereka berbeda minat, cara belajar yang terbaik, dalam memahami gangguan, dan dalam kecepatan mereka belajar. Mereka berbeda dalam pilihan, harapan, motivasi dan kebiasaan kerja. Ada perbedaan antara kemampuan guru dan siswa.

Tujuan organisasi adalah upaya mengembangkan kualitas hasil dan pelayanan dengan mengidentifikasi variasi dalam sistem sehingga mereka dapat bertindak secara menyeluruh. Mengetahui sumber-sumber variasi memungkinkan seorang pmimpin untuk memberi reaksi yang tepat. Dalam sekolah, mengerti sumber-sumber variasi dalam siswa dan kemampuan staf akan memungkinkan kepala sekolah mengambil tindakan yang tepat. Mengapa penting mengerti variasi ? Karena variasi datang dari dua sumber yang berbeda, dan tindakan yang dilakukan harus merespon masing-masing jenis variasi yang berbeda.

Beberapa variasi ada yang sederhana karena sesuatu berbeda secara alamiah. Perbedaan kecepatan belajar siswa, perbedaan tingkat motivasi, kecerdasan, latar belakang, dan kemampuan fisik. Beberapa siswa mungkin mempunyai penyakit lambung, atau sering kelelahan setiap hari. Tidak ada dua siswa, guru, atau kepala sekolah yang sama. Hal ini disebut variasi acak (Random Variation).

Variasi jenis lain yang penting yaitu variasi special cause. Variasi ini ada karena sistem yang menyebabkan dia ada. Jenis variasi ini disebabkan oleh sesuatu yang dikerjakan sistem dan proses yang digunakannya. Proses untuk menghasilkan ban mobil, sebagai contoh, mungkin menghasilkan beberapa ban yang dibawah standar. Pada kasus ini, ban yang di bawah standar 
disebabkan oleh rangkaian khusus dalam proses produksi. Beberapa siswa mungkin tidak belajar aljabar sebaik yang lainnya. Hal ini mungkin disebabkan variasi acak (perbedaan tingkat motivasi, latar belakang dsb). Tapi mungkin juga disebabkan proses pembelajaran atau langkah-langkah yang digunakan guru. Mungkin pengajaran tidak memberikan informasi yang penting. Atau mungkin penjelasan dengan cara yang tidak dimengerti siswa. Atau mungkin tidak cukup waktu untuk latihan yang memadai. Dalam kasus ini, kita bisa menangkap permasalahan dalam pengajaran dan merubahnya sehingga pada saat yang akan datang, persentase siswa yang berhasil makin besar.

Perbedaan dua jenis variasi ini penting untuk seorang pemimpin karena tindakan yang tepat akan berbeda untuk masing-masing kasus.

\section{VARIASI ACAK DAN VARIASI SEBAB KHUSUS DI SEKOLAH}

Ketika banyak variasi di dalam sistem yang diakibatkan oleh sebab khusus, sistem dikatakan tidak stabil, karena kita tidak dapat memprediksi apa yang akan dihasilkan sistem. Kemampuannya akan sporadis dan tidak dapat diprediksi. Hal ini adalah bagian terbesar situasi sekolah saat ini. Meskipun beberapa variasi dalam kemampuan siswa diakibatkan oleh perbedaan yang normal diantara siswa, kebanyakan tidak dapat disalahkan kepada siswa. Proses di dalam sistemnya sendiri yang gagal dan membutuhkan pengembangan dan perbaikan.

Mengambil permasalahan drop out sekolah. Beberapa kasus, drop out diakibatkan oleh perbedaan normal yang ada diantara siswa. Beberapa siswa kurang motivasi atau kurang minat, beberapa kurang mampu, beberapa diakibatkan oleh tantangan ekonomi keluarga. Tapi banyak siswa drop out diakibatkan kesalahan sekolah. Siswa mungkin terlalu sering diperintah, pengajaran yang membosankan, tidak lengkap. Menggunakan sains kualitas artinya kita mencari untuk mengidentifikasi proses di dalam sistem yang mempunyai kontribusi pada permasalahan dan kemudian secara sistematis mengembangkan proses tersebut.

\section{BENCHMARKING}

Dalam dunia bisnis, bencmarks adalah strategi yang efektip dan baik digunakan dalam pengembangan kualitas. Bisnis secara tetap dan sistematis mengukur penampilannya dengan organisasi lain yang sama. Mereka mempelajari organisasi lain yang lebih baik secara tertutup dan menentukan bagaimana mereka dapat mencapai performansi tersebut. 
Sekolah dapat mengadopsi teknik bencmarks sebagai elemen kunci dalam upaya mengembangkan kualitasnya.

\section{LANGKAH MENUJU BENCHMARKING}

Bnechmarking lebih dari sekedar membandingkan satu organisasi dengan lainnya. Namun, benchmarking memfokuskan pada bidang tertentu yang kita ingin untuk mempelajarinya dan menentukan bagaimana baiknya kita bekerja dan kemampuan tingkat mana yang mungkin dapat dilakukan.Oleh karena itu, langkah pertama dalam benchmarking adalah mengidentifikasi sebuah bidang yang ingin kita kembangkan. Bidang ini harus cukup specifik (komunikasi dengan orang tua, pendaftaran, in-service training, atau program pengajaran khusus).

Langkah selanjutnya, setelah mengidentifikasi kebutuhan untuk pengembangan, adalah memilih rekanan benchmarking. Ide memilih rekanan adalah siapa yang sungguh-sungguh terbaik dalam bidang yang ingin kita unggulkan. Tujuan dari benchmarking bukan untuk menunjukan bahwa kita siap sebaik organisasi lain dalam satu bidang. Tujuannya adalah pengembangan. Sehingga kita ingin mengobservasi organisasi yang terbaik melakukan pekerjaan ini dalam bidang tertentu.

Langkah ketiga, adalah memilih tim benchmarking yang akan bekerja. Karena anggota tim nampaknya tidak biasa dengan proses ini, mereka membutuhkan sejumlah bacaan yang baik tentang teknik ini. Umumnya direkomendasikan masing-masing tim ditugaskan pada bidang khusus yang berhubungan dengan proses ini. Masing-masing anggota team dapat merumuskan seperangkat pertanyaan tentang bidang khusus yang menarik.

Langkah selanjutnya adalah kunjungan ke rekanan. Selama di tempat kunjungan. Anggota tim mengobservasi dan bertanya tentang bidang khusus yang menarik perhatiannya dan pertanyaan umum tentang berbagai macam proses.

Langkah terakhir adalah tim berkumpul setelah pulang untuk mengadakan tanya jawab dan berbagi apa yang telah dipelajari di tempat kunjungan. Dengan kegiatan ini, perencanaan dapat dirumuskan untuk membuat pengembangan didasarkan apa yang telah kita pelajari.

\section{PERAN BARU PELANGGAN}

Ahli perubahan melihat secara sungguh-sungguh pentingnya peran pelanggan. Kemajuan bidang telekomunikasi dan internet berimplikasi pada pergeseran peran dari institusi pendidikan 
ke konsumen, siswa dan orang tua. Sebagai konsumen, siswa dan orang tua akan berkesempatan untuk memilih produk pendidikan dan pelayanan yang merespons secara langsung keinginan pribadinya. Hal itu merubah peran konsumen yang menjadikan kualitas sebagai isu dari kelangsungan bisnis Amerika. Hal ini akan menjadi masukan untuk pendidikan.

\section{SEKOLAH VIRTUAL}

Untuk melayani perluasan dan keinginan yang bervariasi dari pelanggan, sekolah mungkin harus menjadi lebih kepada sekolah maya, dimana seluruh kekuatan dan kemampuan sekolah tidak hanya dalam bentuk sekolah seperti sekarang ini. Hal itu mirip sekolah dari segi fungsi dan kebutuhannya, tapi lebih serba guna yang bisa ada pada setiap waktu dan dimana saja. Sekolah maya sebagai sumber informasi, pengetahuan, sumber belajar, tempat kerja. Dibanding sekolah tradisional, sekolah maya lebih menyerupai jaring laba-laba.

Satu kunci untuk mendesain sekolah virtual adalah mengembangkan kemampuan teknologi untuk mendukung pembelajaran dimana saja, kapan saja. Teknologi baru ini akan membutuhkan pemeliharaan yang terintegrasi dan selalu berubah sesuai dengan kemajuan siswa secara individual pada berbagai pelajaran., dan mereka akan membutuhkan penyediaan siswa dengan penyusunan sumber belajar yang dikembangkan dengan baik, dan metodologi instruksional. Artinya, setiap orang harus mengembangkan sistem manajemen pembelajaran yang lebih berpengalaman.

\section{MENGUKUR KEPUASAAN PELANGGAN}

Satu tantangan yang prinsip dalam menggunakan sains kualitas adalah mengukur kepuasaan pelanggan. Memperoleh pandangan pelanggan tentang keefektipan produk organisasi dan pelayanan adalah dasar untuk semua penerapan sains kualitas. Kebutuhan mengukur kepuasan pelanggan adalah menyediakan pengelolaan dengan pandangan pelanggan bagaimana baiknya pelayanan pelanggan. Yang disayangkan, dalam pendidikan, kita belum menggunakan metode pengetahuan untuk mengukur tingkat kepuasaan pelanggan.

Mengukur kepuasaan pelanggan melibatkan proses yang lebih ilmiah, tepat dan luas dibanding seperti yang dilakukan sekarang dengan survey yang hanya menanyakan puas atau tidak puas tanpa dapat mengidentifikasi dimana kegagalan proses dan mengapa. Mereka mengukur 
sikap umum orang tentang organisasi dibandingkan dengan memperoleh informasi tentang permasalahan khusus, dan mereka tidak mengukur frekuensi dan jenis komplain pelanggan.

Pendekaran sains kualitas menggunakan survey dan kuosioner yang dikirim ke rumah pelanggan dan pelanggan lainnya, tapi dalam kasus ini, kuosioner dirancang untuk mengukur halhal khusus dari ketidakpuasan diantara kelompok pelanggan khusus. Sebagai contoh, satu kuosioner didesain untuk orang tua, yang lain untuk siswa, dan ketiga untuk komunitas bisnis. Kuosioner ini mencari informasi yang sangat khusus tentang sejumlah dan jenis perhatian atau pertanyaan pelanggan yang telah berpengalaman dengan sekolah.

\section{MENGAPA MEMBAYAR UNTUK MEMBERIKAN PELAYANAN PELANGGAN}

Mengapa perusahaan mau menginvestasikan sejumlah uang untuk memberikan pelayanan pada pelanggan ? Alasannya sederhana, kepuasaan pelanggan menghasilkan kesetiaan pelanggan. Dan kesetiaan pelanggan berarti penambahan keuntungan untuk perusahaan.

Apakah kesetiaan pelanggan penting untuk sekolah ? Ya, sekolah (apakah negeri atau swasta) tergantung pada pelanggannya untuk keberadaannya.

\section{KUALITAS YANG DIPANDU PELANGGAN}

Customer driven quality artinya kita secara sungguh-sungguh mengerti kebutuhan, keinginan, dan harapan dari pelanggan kita. 


\section{BAB 7}

\section{ALAT-ALAT SAINS KUALITAS}

Sains kualitas menyediakan seperangkat metode yang dipercaya dan menjamin untuk pencapaian keunggulan dalam organisasi. Oleh karena itu, penting, bahkan bagian utama dalam pengembangan dunia pendidikan.

Pengembangan kualitas belakangan mempublikasikan seri artikel yang umum disebut "Tujuh alat Kualitas". Dengan menggunakan tujuh alat dasar ini, orang dapat berhasil menetapkan proses pengembangan kualitas dalam sistem pendidikan.

Alat-alat yang digunakan dalam sains kualitas adalah :

- Diagram sebab akibat

- Grafik kontrol

- Histogrsm

- Lembar periksa

- Grafik Pareto

- Diagram pencar

- Flowchart 


\section{BAB 8 MANAJEMEN PERUBAHAN}

Pemimpin pendidikan yang ingin memandu organisasinya ke dalam realitas yang baru akan membutuhkan untuk mengerti dinamika perubahan dan dapat menguasai keahlian memanage perubahan. Management perubahan adalah kunci teknologi yang harus dikuasai untuk memandu kesuksesan perubahan.

Kesuksesan implementasi dari perubahan dalam organisasi mengikuti pola yang berbeda, ada kekuatan yang dapat diidentifikasi yang membentuk kesuksesan. Memanage perubahan adalah proses yang bisa dan sudah dipelajari. Tanpa kualitas kepemimpinan dan kecakapan management , ide-ide terbaik tidak pernah akan dapat diimplementasikan.

\section{ASAL MANAGEMENT PERUBAHAN}

Sumber dari pengetahuan baru ini tentang perubahan datang dari literatur bisnis dalam pengembangan organisasi dan transformasi organisasi. Hal ini merupakan lapangan yang relatif baru.

\section{MANAGEMENT PERUBAHAN SEBAGAI TEKNOLOGI}

Management perubahan adalah seperangkat tindakan dan taktik untuk memahami dan memandu perubahan dalam organisasi. Strategi dan taktik ini ditujukan untuk membangun iklim yang lebih positif untuk perubahan yang memungkinkan pemimpin dan manusia bekerja dalam organisasi untuk menerapkan perubahan dengan sukses. Strategi dan kegiatan ini juga memungkinkan pemimpin bekerja dengan sisi kemanusiaan dari perubahan dimana cara proaktif dengan mengerti respon dan emosional pribadi dan keadaan yang selalu muncul selama proses perubahan.

Management perubahan adalah teknologi yang memandu perubahan yang memungkinkan pemimpin untuk :

- Membantu orang bersedia, menerima dan menjadi melakukan perubahan

- Mengerti peran orang yang berbeda dalam proses perubahan

- Mengetahui seberapa banyak perubahan 
- Mengerti tahapan perubahan dan strategi perubahan yang pantas pada masing-masing tahapan

- Mengetahui kapan terjadi resistensi

- Mengetahui bagaimana merubah resistensi ke dalam sesuatu yang membangun

\section{PERUBAHAN DALAM PENDIDIKAN}

Hampir semua orang yang bekerja dalam pendidikan mempunyai keyakinan bahwa perubahan dalam pendidikan adalah kompleks. Setiap waktu gagasan baru diluncurkan, disana ada efek tepi dan konsekuensi yang tidak terduga yang kekuatannya bahkan lebih optimis untuk menerima sistem alamiah dan ragu untuk mencoba perubahan dalam pendidikan.

\section{TAHAPAN PERUBAHAN}

Daryl Corner's group, Organization Development Resources (ODR), telah mempelajari bagaimana perubahan besar telah dilakukan dalam organisasi besar. Mereka mengobservasi bahwa perubahan hampir selalu mengikuti urutan pola yang dapat diprediksi. Salah satu dari pola itu terdiri dari tiga tahap : persiapan, penerimaan, dan pelaksanaan. Untuk merubah keberhasilan, pemimpin harus membantu mereka dengan pengawasan yang cukup pada ketiga fase itu. Dalam tahap persiapan, dimana orang-orang yang terlibat dalam perubahan berupaya sadar kebutuhan akan perubahan, dan mengerti usulan perubahan akan berpengaruh pada peran pribadinya dan tanggungjawabnya. Mereka mungkin bingung dan tidak jelas tentang sifat perubahan. Selama tahap ini, mereka mungkin tidak setuju bahwa perubahan itu penting. Peran dari pemimpin menyediakan informasi yang akan membantu untuk menghilangkan kebingungan, memberikan informasi tentang mengapa perubahan itu penting,

Orang masuk ke dalam tahap penerimaan ketika merka mengerti sifat dan kepentingan perubahan dan mulai menerima gagasan bahwa perubahan itu penting. Indikator bahwa orang bergerak ke dalam tahap penerimaan dimana mereka sekarang melihat perubahan sebagai kenyataan. Disini tidak berarti bahwa sikap setiap orang tentang perubahan itu positif. Bahkan setelah perubahan terbentuk dengan masukan yang membangun, disana tetap ada sikap positip dan negatif. Yang paling penting, untuk keberhasilan perubahan, pemimpin organisasi harus menjamin bahwa orang-orang kunci dalam organisasi telah masuk pada tahap penerimaan.

Tahapan ketiga adalah tahap komitmen. Tahap ini tidak mulai hingga orang memutuskan untuk bersatu dengan perubahan. Bahkan mereka memutuskan mulai dengan perubahan dan 
orang akan berperan dalam aspek tertentu dalam perubahan. Peran dari manager pada tahap ini adalah memelihara lingkungan kerja yang terbuka dengan usulan diskusi terbuka untuk mengidentifikasi dan memecahkan masalah dan membangun semangat team dan komitmen kelompok. Tahap komitmen mungkin menunjukan keputusan untuk mengadopsi perubahan untuk ujicoba. Hasil dari tahap komitment adalah dapat atau tidak dapat mengadopsi, karena hasil uji coba mungkin tidak cukup memadai. Jika setelah periode ujicoba, kita menentukan bahwa perubahan itu positif, tahap ini akan mengarahakan ke institusionalisasi.

\section{PERAN-PERAN KUNCI}

Hasil observasi lain yang penting dari ODR adalah bahwa keberhasilan perubahan tergantung pada kesuksesan kemampuan dari orang-orang kunci dalam empat peran yang berbeda : Peran sebagai sponsor, agen, advocate dan targets.

Sponsor, adalah orang dalam posisi sebagai ahli-individu yang mempunyai kekuasaan dalam perubahan, memasang prioritas baru, alokasi dana, dan meluangkan waktu yang dibutuhkan dari pekerjaan yang tetap dalam mendesain perubahan. Sponsor juga bertanggung jawab untuk membuat lingkungan yang dapat memungkinkan perubahan dapat berhasil diterapkan.

Agent, adalah individu dalam organisasi yang bertanggungjawab untuk membuat perubahan terjadi. Agent mengembangkan perencanaan untuk melaksanakan perubahan, mendiagnosa masalah yang potensial yang dapat membatasi implementasi dari perubahan.

Advocates, adalah individu yang ingin membuat perubahan tapi tidak mempunyai kekuatan / hak.

Targets, adalah individu yang harus melaksanakan perubahan.

\section{TAHAPAN KEKHWATIRAN}

Perubahan, secara alamiah, adalah mengacaukan dan tidak menyenangkan. Kebiasaan orang dipengaruhi, kemudian merencanakan dan mengharapkan perubahan. Karena secara alamiah perubahan mengacaukan dan tidak menyenangkan, secara alamiah orang akan mengalami berbagai kekhawatiran, emosi, dan reaksi sebagai proses pengalaman mereka. Gene Hall, telah mempelajari kekhawatiran, perasaan dan reaksi orang yang harus berubah karena mereka terlibat 
di dalamnya. Apa yang Hall dapatkan dari perasaan dan persepsi orang tentang perubahan dapat dikategorikan ke dalam tiga tife kekhawatiran :

- kekhawatiran tentang bagaimana perubahan akan berpengaruh pada dirinya sendiri (self concern)

- kekhawatiran tentang bagaimana melakukannya (task concern) dan

- kekhawatiran tentang bagaimana membuat perubahan yang terbaik (impact concern)

Hall juga mencatat bahwa, dalam proses memange perubahan yang baik, perkembangan kekhawatiran orang melalui tiga tahap dalam pola yang dapat diprediksi. Tiga tahapan kekhawatiran yang dapat diidentifikasi pada tiga tahap perubahan (persiapan, penerimaan, dan komitment).

Prosedur untuk menilai kekhawatiran, menggunakan metode yang melibatkan kombinasi dari :

- percakapan informal

- $\quad$ orang menulis deskripsi kekhawatiran mereka

- kuosioner

\section{RESISTENSI : REAKSI ALAMIAH DARI PERUBAHAN}

Perubahan itu mengacaukan, menyebabkan pengaruh yang tidak terduga, membuat tekanan dan membuat emosi orang muncul. Perubahan selalu tidak menyenangkan. Karena perubahan tidak menyenangkan maka selalu ada resistensi.

Manager yang efektif untuk perubahan menyadari hal ini, dan tidak akan memandang resistensi sebagai masalah, atau bahkan lebih buruk, memandang seseorang yang resisten tidak loyal, dungu atau berpikiran tertutup. Malahan, seorang manager yang efektif untuk perubahan akan menggunakan resistensi dan orang-orang yang resisten sebagai bagian dari solusi dibandingkan melihatnya sebagai masalah. Kunci dari membuat resistensi menjadi solusi adalah membuat resistensi dapat diterima dengan menghargai orang yang bertahan secara terbuka.

Pengalaman telah mengajarkan kepada kita bahwa tidak ada orang atau kelompok dapat melihat pengaruh total dari perubahan atau bagaimana hal itu mempengaruhi setiap aspek kegiatan atau setiap orang dalam organisasi. Hal ini disebabkan perubahan selalu bersifat tempelan dari sistem yang besar. Dengan berfikir sistem, semua perubahan akan mempunyai pengaruh pada setiap bagian dari sistem. Pandangan, pengalaman dan masukan dari manager, orang tua, guru dan 
lainnya akan berbeda memandang perubahan sebagai bagian dari keseluruhan. Masing-masing individu atau kelompok yang berpartisipasi dalam proses perubahan dapat mempengaruhi perubahan menjadi lebih baik.

\section{PENGARUH DARI KULTUR PERUSAHAAN}

Setiap organisasi, meliputi sekolah, mempunyai kultur yang meliputi keseluruhannya. Kulur terdiri dari keyakinan dan asumsi tentang bagaimana organisasi berjalan dan apa misi yang diembannya. Dalam dunia bisnis, seperangkat keyakinan dan asumsi tentang bisnis dan prakteknya disebut kultur perusahaan, yaitu cara bisnis berfikir tentang dirinya dan apa yang dikerjakannya. Setiap institusi, bisnis, perusahaan dan setiap sekolah mempunyai kultur perusahaan - seperangkat pola kebiasaan yang mempengaruhi bagaimana fungsi bisnis, perusahaan dan sekolah.

Keyakinan, nilai, dan pola kebiasaan yang dimasukan ke dalam kultur membawa pengaruh yang sangat besar. Seperti listrik, kultur memberikan aliran kepada seluruh sistem dan mempengaruhi sesuatu yang terjadi. Kultur mempunyai kehidupannya sendiri. Dia mempunyai kekuatan dan pengaruh sendiri,; kebiasaannya tumbuh kuat mungkin memerlukan waktu yang lama. Membentuk perilaku dari setiap orang dalam organisasi dan bisa dikontrol.

Kultur organisasi mempengaruhi perubahan dengan mengendalikan gagasan, keputusan atau kegiatan yang tidak konsisten dengan kultur yang ada. Jika perubahan yang kita inginkan, secara umum dapat diterima oleh kultur yang ada kita bisa berharap tingkat kesuksesan yang tinggi. Jika, di sisi lain, perubahan yang kita usulkan mempunyai sedikit keumuman dengan kultur yang ada atau bertentangan dengan kecenderungan kultur yang ada, kesuksesan yang dicapai dalam perubahan sedikit sekali. 


\section{BAB 9}

\section{ALAT-ALAT MANAGEMENT PERUBAHAN}

Perubahan itu tidak misterius atau tidak dapat dipahami. Kita sekarang mengerti bahwa ada kepercayaan dan tahap yang dapat diprediksi dan kejadian yang menjadi sifat dari perubahan. Dengan mengerti tahapan dan kejadian dari perubahan itu penting untuk menghasilkan keuntungan dan menolak kegagalan yang menjadi bagian bagi perubahan organisasi.

Alat-alat yang dapat digunakan untuk membantu memage perubahan adalah :

- Daftar cek untuk perubahan

- Penilaian resistensi

- Digram komitmen

- Daftar penjelasan perubahan

- Skala waktu perubahan

- Skala tingkat penggunaan 


\section{BAB 10 \\ TEKNOLOGI INSTRUKSIONAL}

Hal utama yang telah kita pelajari adalah bahwa mengajar dan belajar dapat diperlakukan secara ilmiah. Kita sekarang bisa menentukan dengan kepastian apa yang siswa inginkan untuk dipelajari untuk membentuk kemampuan yang lebih baik pada bidang tertentu. Kita dapat mendiagnosa masalah belajar atau gap antara pemahaman siswa dari mata pelajaran agar dapat membantu mereka dengan kebutuhan dan permasalahan belajarnya. Kita juga memiliki cara yang lebih baik untuk mengukur pemahaman siswa sehingga kita tidak membuang waktu dengan mengajar apa yang telah diketahui siswa.

Teknologi pembelajaran memberi kita teknik ilmiah untuk menghasilkan pengembangan dalam cara siswa belajar dan cara kita menyajikan pengajaran kepada mereka. Hal itu meliputi kegiatan dan langkah yang memungkinkan kita untuk :

- Menjelaskan pembelajaran apa yang harus dilakukan

- Menentukan apakah siswa telah dapat bekerja yang sesuai dengan tujuan akhir

- Mengembangkan, uji coba dan revisi pembelajaran yang akan memungkinkan siswa menjadi lebih baik

- Mengimplementasikan pembelajaran individual atau dengan seting kelompok

- Mengevaluasi bagaimana pembelajaran yang baik dikerjakan dengan siswa

- Mengembangkan pembelajaran sehingga bekerja lebih baik pada waktu selanjutnya

Teknologi pembelajaran, adalah proses ilmiah yang digunakan untuk mengembangkan ,menerapkan dan memanfaatkan produk dan program pembelajaran. Sayangnya, kebanyakan program di sekolah-sekolah sekarang tidak memakai cara ini.

\section{TEKNOLOGI PEMBELAJARAN DAN PERALATAN ELEKTRONIK}

Teknologi pembelajaran terdiri dari cara praktis yang secara langsung dapat mengubah kemampuan manusia. Meliputi langkah yang praktis, untuk menggunakan komputer dan alat multimedia untuk menyampaikan pengajaran secara langsung kepada siswa atau merupakan bagian pelengkap dari penyajian verbal guru. Sistem kita sekarang tergantung pada banyaknya penyajian guru, dan pembelajaran kelompok dibandingkan pembelajaran individual dan tidak sungguh-sungguh menggunakan peralatan pembelarajan elektronik yang baru. Peralatan 
elektronik sekarang dan masa yang akan datang mempunyai kemampuan untuk mengembangkan aktifitas pendidikan dengan cara-cara yang tidak terbayangkan pada beberapa tahun silam.

Jika peralatan ini sangat baik, mengapa kemudian belum mempengaruhi pengembangan produktifitas siswa dan pembelajaran di sekolah? Sebabnya adalah peralatan pembelajaran dengan teknologi tinggi telah digunakan hanya pada sebagian kecil aktifitas di sekolah dan tidak merubah aspek lain yang mempengaruhi dalam pembelajaran.

\section{INSENTIF DAN PENGHARGAAN}

Sekolah telah menghasilkan sedikit produktifitas dengan penambahan peralatan yang utama karena hanya ada sedikit insentif yang diberikan. Karena sistem sekolah terutama yang dikontrol pemerintah dan birokrasi, tidak ada kekuatan pasar yang menjadi dasar kompetisi yang ditekankan pada organisasi lain (seperti bisnis dan rumah sakit) untuk menanam inovasi bagi pengembangan produktifitas dan pelayanan terbaik untuk para pelanggan.

Faktor kunci dalam pengembangan adalah bukan sifat mementingkan orang lain, kemauan yang baik, atau kualitas program. Kunci itu adalah kompetisi. Kompetisi yang membuat perusahaan dan eksekutif bisnis mempertanggungjawabkan biaya dan hasil. Kekurangan kompetisi dalam pendidikan menyebabkan kekurangan pertanggungjawaban pada area yang sama.

Karena sekolah negeri adalah monopoli pemerintah, tentunya tidak ada dorongan segi ekonomi dari luar untuk pendidik atau administator untuk mengadopsi inovasi atau pengembangan. Sekolah tidak pernah menawarkan penghargaan atau bahkan harapan, untuk staf yang profesional untuk mengadopsi produktifitas untuk mereka dan siswanya.

Secara alamiah, orang akan bekerja keras, lebih kreatif, inovatif dan produktif, jika mereka punya keuntungan pribadi dari hasil usahanya. Hanya ketika mereka mendapatkan sesuatu dari pekerjaannya, mereka menjadi sangat bertanggung jawab denga apa yang ia kerjakan dan apa yang mereka tidak kerjakan.

\section{PARADOKS PRODUKTIFITAS}

Membelanjakan sebagian besar dana pendidikan untuk mesin elektronik tidak akan, meningkatkan produktifitas. Pertanyaan mengapa investasi yang besar dalam peralatan modern 
tidak menghasilkan pencapaian produktifitas, dikenal dengan paradoks produktivitas. Penjelasannya nampaknya bahwa investasi alat dengan teknologi tinggi tidak mengubah produktifitas jika peralatan itu digunakan sederhana sebagai pengganti proses yang lama.

Pemerikasaan dengan teliti proses kerja, merubah sifat alamiah tugas dan proses berfikir kembali disebut sebagai "perekayasaan". Jika sistem pendidikan kita untuk menjadi lebih baik, kita harus mereorganisasi cara kita bekerja dan belajar sehingga kita bisa mendapat keuntungan penuh dari peralatan elektronik. Hal ini tidak dapat dilakukan hanya dengan menggunakan alat sebagai pelengkap pengajaran tradisional atau model kelas. Jenis pekerjaan baru yang berbeda dan pola staf harus muncul dari guru dan personel sekolah lainnya. 


\section{BAB 11}

\section{ALAT - ALAT TEKNOLOGI PEMBELAJARAN}

Teknologi pembelajaran menggunakan langkah-langkah ilmiah untuk mengembangkan, mengevaluasi dan meningkatkan program dan hasil pembelajaran sehingga sehingga mereka dapat mencapai keefektipan yang optimal. Hal itu berkenaan dengan seluruh metode dan seperangkat teknik yang dikerjakan pada proses instruksional. Hal itu meliputi analisis yang rinci dari pelajaran yang dipelajari, membentuk penyajian pelajaran ke dalam urutan yang baik, memilih dan menggunakan media, dan menggunakan metode penilaian yang memadai untuk mengevaluasi keefketifan dari pembelajaran.

Peralatan yang digunakan dalam teknologi pembelajaran yaitu :

- Model desain instruksional

- Ketepatan menuliskan tujuan

- Analisis tugas

- Diagram pemilihan media

- Uji coba dan revisi instruksional

- Pilihan software pendidikan

- Perangkat multimedia 